\title{
IMPLEMENTASI METODE SIMPLEKS DALAM PENENTUAN JUMLAH PRODUKSI UNTUK MEMAKSIMASI KEUNTUNGAN
}

\author{
Qhory Riana Al Vonda ${ }^{1}$, Firra Dinni ${ }^{2}$, Destryan Dyah Saputra ${ }^{3}$, Ira Puspita ${ }^{4}$, \\ Ilham Falani ${ }^{5}$, Elfitria Wiratmani ${ }^{6}$ \\ Program Studi Teknik Industri, Universitas Indraprasta PGRI Jakarta \\ Jl. Raya Tengah No. 82 RT 6/1, Gedong, Ps Rebo, Kota Jakarta Timur, Daerah Khusus Ibukota \\ Jakarta 13760 \\ qhoryalvonda18@gmail.com ${ }^{1}$, firradinni9@gmail.com²,destryanp@gmail.com ${ }^{3}$, \\ irapuspita164@gmail.com ${ }^{4}$, ilhamfalani@gmail.com ${ }^{5}$,elfitriaw@gmail.com ${ }^{6}$
}

Submitted May 9, 2019; Revised July 5, 2019; Accepted July 20, 2019

\begin{abstract}
Abstrak
Permasalahan dalam perencanaan produksi pada PT KBDTI dapat dipandang sebagai model linear programming, dengan tujuan untuk menentukan jumlah produksi untuk masing-masing varians sehingga diperoleh keuntungan yang maksimal. Perencanaan produksi yang dimodelkan tersebut tentu harus mempertimbangkan kendala-kendala yang dihadapi perusahaan. Perlu adanya metode yang tepat dalam pencarian solusi linear programming. Salah satunya adalah metode simpleks. Metode Simpleks merupakan salah satu metode yang tepat untuk digunakan pada linear programming yang memiliki variabel lebih dari dua dengan fungsi kendala yang kompleks. Kasus yang terjadi pada PT KBMDI yaitu perusahaan ingin memiliki laba optimal dari setiap varians produk, laba yang diperoleh dari varians ekstrak buah dengan mempertimbangan semua keterbatasan yang ada. Pengolahan data metode simpleks untuk linear programming pada penelitian ini dilakukan dengan bantuan $Q M$ for Windows. Berdasarkan hasil perhitungan menggunakan software QM For Windows terjadi peningkatan keuntungan pada PT KBDTI sebesar 57\% dibandingkan dengan keuntungan pada PT KBDTI sebelumnya.
\end{abstract}

Kata kunci: optimasi, linear programming, simpleks

\begin{abstract}
The problem in production planning at PT KBDTI can be seen as a linear programming model, with the purpose to determine the amount of production for each variant to gain maximum profit. The modeled production planning must certainly consider the constraints faced by the company. There needs to be an appropriate method in finding linear programming solutions. One of them is simplex method. Simplex method is one of the correct method to use on linear programming with more than two variables with a complex constraint functions. The case in PT KBDTI is that the company wants to have an optimal profit from each products variant, profits gained from fruits extract variant considering every available boundaries/limitations. Simplex methods data processing for linear programming in this research is done with the help of QM for Windows. Based on the results of calculations using QM For Windows software, there was an increase in profits at PT KBDTI by 57\% compared to the profits at PT KBDTI before.
\end{abstract}

Keywords: optimization, linear programming, simplex

\section{PENDAHULUAN}

Persaingan dalam dunia industri semakin ketat, hal tersebut membuat perusahaan ingin unggul di antara perusahaan kompetitor lainnya, salah satunya yaitu unggul dalam memperoleh keuntungan.
Tetapi pada kenyataannya untuk memperoleh keuntungan yang maksimal, perusahaan dipengaruhi oleh kendalakendala yang dialaminya. PT KBDTI merupakan perusahaan yang bergerak dalam bidang manufaktur yang 
memproduksi ekstrak buah dengan berbagai macam varians rasa. Perusahaan yang terletak di Jl. Kavling DPR No 8 Serua, Bojong Sari, Depok ini memiliki kendala dalam perencanaan produksinya karena fluktuasi permintaan dan fluktuasi harga bahan baku yang tergantung terhadap musim, tenaga kerja, serta lamanya waktu produksi. Perencanaan produksi pada PT KBDTI dapat dipandang sebagai model linear programming, dengan tujuan untuk menentukan jumlah produksi untuk masing-masing varians sehingga diperoleh keuntungan yang maksimal. Suatu masalah maksimasi, dikenal fungsi objektif atau fungsi tujuan yang merupakan fungsi pengevaluasi yang ingin dioptimalkan [1]. Teknik pemrograman linier merupakan model optimalisasi alokasi sumber daya untuk mencapai efisiensi dalam perencanaan produksi [2]. Pemrograman linier merupakan model matematis yang paling sering diterapkan karena dianggap lebih optimal dalam mencari solusi optimal Pemrograman linier adalah teknik penelitian operasi yang banyak digunakan dalam menemukan solusi untuk masalah keputusan manajerial [3], [4]. Dengan demikian, metode linear programming merupakan solusi optimal dengan model matematis yang mampu membantu perusahaan dalam alokasi sumber daya untuk mencapai efisiensi perencanaan perusahaan. Perlu adanya metode yang tepat dalam pencarian solusi linear programming. Salah satunya adalah metode simpleks. Metode Simpleks merupakan salah satu metode yang tepat untuk digunakan pada linear programming yang memiliki variabel lebih dari dua dengan fungsi kendala yang kompleks. Metode simpleks dapat digunakan sebagai alat analisis suatu perusahaan yang meggunakan banyak input dalam proses produksi dengan tujuan memperoleh keuntungan [5]. Metode Simpleks menyediakan cara sistematis untuk memeriksa simpul dari wilayah yang layak untuk menentukan nilai optimal dari fungsi tujuan. Fungsi tujuan secara matematis yang terdapat pada perusahaan dengan $x_{1}$ merupakan fungsi kendala, sedangkan $s_{1}$ sebagai slack atau variabel tambahan. Penelitian ini bertujuan untuk memaksimalkan keuntungan perusahaan. Sehingga fungsi tujuan dibuat dalam persamaan sebagai berikut [6], [7], [8]:

$$
\operatorname{Zmax}=\mathrm{c}_{1} x_{1}+c_{2} x_{2}+\cdots+\mathrm{c}_{\mathrm{n}} x_{n}
$$

Keterangan :

Zmax = Keuntungan maksimum

$\mathrm{c} \quad=$ Koefisien

$x_{i} \quad=$ Variabel, untuk $i=1 \cdots n$

Ini adalah metode berulang. Dalam metode ini, satu hasil bertahap dari satu solusi dasar yang layak ke yang lain sedemikian rupa [9].

\section{METODE PENELITIAN}

Jenis penelitian yang dilakukan memiliki tujuan studi adalah studi obsevasi. Observasi menjadi salah satu metode pengumpulan data dari metode pengumpulan data lainnya seperti wawancara, konseling, observasi, dll [10]. Metodologi yang dilakukan dalam penelitian ini adalah metode studi pustaka untuk mempelajari Metode simpleks yang digunakan sebagai alat analisis suatu perusahaan dengan tujuan memperoleh keuntungan. Dari hasil studi pustaka ini dilakukan sebuah implementasi metode simpleks untuk menentukan keuntungan yang optimal. Implemetasi dilakukan dengan menggunakan software QM For Windows. Hasil dari penentuan solution result ini diharapakan dapat membantu perusahaan dalam perencanaan produksi yang tepat.

\section{HASIL DAN PEMBAHASAN}

PT KBDTI merupakan perusahaan yang bergerak pada bidang manufaktur dengan memproduksi berbagai varians ekstrak 
buah, varians rasa yang dihasilkan yaitu ekstrak buah jambu biji merah, ekstrak buah sirsak, ekstrak buah nanas, ekstrak buah manga dan ekstrak buah lemon. Ketersediaan buah perminggu yaitu buah jambu biji merah sebanyak $80000 \mathrm{~kg}$, buah sirsak sebanyak $50000 \mathrm{~kg}$, buah nanas sebanyak 35000, buah mangga sebanyak $75000 \mathrm{~kg}$ dan buah lemon sebanyak 25000 $\mathrm{kg}$ sedangkan ketersediaan bahan baku penunjang yaitu asam sitrat sebanyak 300 $\mathrm{kg}$, fruktosa $600 \mathrm{~kg}$, tenaga kerja yang dipekerjakan di PT KBDTI yaitu sebanyak 20 orang pada bagian produksi, serta dalam satu minggu PT KBDTI membutuhkan waktu produksi selama 90 jam. Adapun keuntungan yang diperoleh PT KBDTI untuk hasil produksi setiap minggunya sebelum menggunakan metode simpleks adalah sebesar Rp. 600.000.

Pada PT KBDTI terjadi kendala pada fluktuasi permintaan sehingga bahan baku yang digunakan sering terjadi kurang, bukan hanya bahan baku, tenaga kerja dan waktu pemrosesan produksi. Berikut adalah data tabel kendala yang ada di PT KBDTI :

\section{Tabel 1. Data Kendala PT KBDTI}

\begin{tabular}{ccccccc}
\hline Uraian & $\boldsymbol{X}_{\mathbf{1}}$ & $\boldsymbol{X}_{\mathbf{2}}$ & $\boldsymbol{X}_{\mathbf{3}}$ & $\boldsymbol{X}_{\mathbf{4}}$ & $\boldsymbol{X}_{\mathbf{5}}$ & Tersedia \\
\hline Buah Jambu & 13 & 0 & 0 & 0 & 0 & 80000 \\
Buah Sirsak & 0 & 12 & 0 & 0 & 0 & 50000 \\
Buah Nanas & 0 & 0 & 15 & 0 & 0 & 35000 \\
Buah Mangga & 0 & 0 & 0 & 13 & 0 & 75000 \\
Buah Lemon & 0 & 0 & 0 & 0 & 20 & 25000 \\
Fruktosa & 23 & 21 & 22 & 25 & 25 & 600 \\
Asam Sitrat & 10 & 5 & 7 & 8 & 9 & 300 \\
Tenaga Kerja & 1 & 1 & 1 & 1 & 1 & 20 \\
Waktu & 3 & 3 & 3 & 3 & 3 & 90 \\
\hline Keuntungan & 32500 & 60000 & 35000 & 45000 & 87500 & \\
\hline Sumber: PT KBDTI & & \multicolumn{5}{l}{}
\end{tabular}

Penyelesaian dari masalah yang dihadapi PT KBDTI yaitu dengan menggunakan linear programming menggunakan metode simpleks terdiri atas definisi variabel, fungsi tujuan, serta keterbatasan atau fungsi kendala yang dimiliki perusahaan. Adapun penjelasan dalam bentuk fungsi adalah sebagai berikut:

Definisi Variabel :

$x_{1}=$ produk ekstrak buah rasa jambu (liter)

$x_{2}=$ produk ekstrak buah rasa sirsak (liter)

$x_{3}=$ produk ekstrak buah rasa nanas (liter)

$x_{4}=$ produk ekstrak buah rasa mangga (liter)

$x_{5}=$ produk ekstrak buah rasa lemon (liter)

Fungsi Tujuan :

Maks : $\mathrm{Z}=32500 x_{1}+60000 x_{2}+$ $35000 x_{3}+45000 x_{4}+87500 x_{5}$
Fungsi Kedala :

$13 x_{1} \leq 80000$ (Bahan baku buah jambu) $13 x_{1} \leq 80000$ (Bahan baku buah jambu) $12 x_{2} \leq 50000$ (Bahan baku buah sirsak) $15 x_{3} \leq 35000$ (Bahan baku buah nanas) $13 x_{4} \leq 75000$ (Bahan baku buah mangga) $20 x_{5} \leq 25000$ (Bahan baku buah lemon) $23 x_{1}+21 x_{2}+22 x_{3}+25 x_{4}+25 x_{5} \leq$ 600 (Fruktosa)

$10 x_{1}+5 x_{2}+7 x_{3}+8 x_{4}+9 x_{5} \leq 300$ (Asam sitrat)

$x_{1}+x_{2}+x_{3}+x_{4}+x_{5} \leq 20$ (Tenaga kerja) $3 x_{1}+3 x_{2}+3 x_{3}+3 x_{4}+3 x_{5} \leq 90$ (Jam kerja)

$50 x_{1} \geq 130$ (Permintaan ekstrak jambu)

$40 x_{2} \geq 120$ (Permintaan ekstrak sirsak)

$60 x_{3} \geq 150$ (Permintaan ekstrak nanas)

$45 x_{4} \geq 130$ (Permintaan ekstrak mangga)

$75 x_{5} \geq 200$ (Permintaan ekstrak lemon)

$$
x_{1}, x_{2}, x_{3}, x_{4}, x_{5} \geq 0
$$


Berikut adalah Pengolahan data metode simpleks secara manual dengan beberapa langkah simpleks sebagai berikut:

1. Mengubah fungsi tujuan

$\mathrm{Z}=32500 x_{1}+60000 x_{2}+35000 x_{3}+$ $45000 x_{4}+87500 x_{5}$ menjadi, $\mathrm{Z}-32500$ $x_{1}-60000 x_{2}-35000 x_{3}-45000 x_{4}-$ $87500 x_{5}$

2. Menyusun persamaan-persamaan ke dalam tabel serta memilih kolom kunci dan memilih baris kunci

3. Menyusun persamaan-persamaan ke dalam tabel serta memilih kolom kunci dan memilih baris kunci
Fungsi koefisien dalam linear programming tersebut akan disusun dan diberi variabel slack dengan simbol $s_{i}$, karena kendala terdapat pertidaksamaan berbentuk $\geq$ maka pertidaksamaan $\geq$ diubah dengan menambah variabel buatan yaitu $r_{i}$ dan cara menyelesaikan pertidaksamaan $\geq$ metode simpleks dengan menggunakan teknik $M$ [9]. Teknik $M$ ini merupakan suatu bilangan positif yang nilainya sangat besar, maka fungsi $\mathrm{Z}$ akan diubah sebagai berikut:

\begin{tabular}{|c|c|c|c|c|c|c|}
\hline L & $x_{1}$ & $x_{2}$ & $x_{3}$ & $x_{4}$ & $x_{5}$ & $s_{1} s_{2} s_{3} s_{4} s_{5} s_{6} s_{7} s_{8} s_{9} s_{10} s_{11} s_{12} s_{13} s_{14} r_{1} r_{2} r_{3} r_{4} r_{5} \mathrm{NK}$ \\
\hline M $[1$ & -32500 & 60000 & .35000 & -45000 & .87500 & 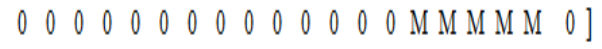 \\
\hline M $[0$ & 50 & 0 & 0 & 0 & 0 & $\left.\begin{array}{lllllllllllllllllllll}0 & 0 & 0 & 0 & 0 & 0 & 0 & 0 & 0 & -1 & 0 & 0 & 0 & 0 & 1 & 0 & 0 & 0 & 0 & 130\end{array}\right]$ \\
\hline M $[0$ & 0 & 40 & 0 & 0 & 0 & $\left.\begin{array}{llllllllllllllllllllll}0 & 0 & 0 & 0 & 0 & 0 & 0 & 0 & 0 & 0 & -1 & 0 & 0 & 0 & 0 & 1 & 0 & 0 & 0 & 120\end{array}\right]$ \\
\hline M $[0$ & 0 & 0 & 60 & 0 & 0 & $\left.\begin{array}{llllllllllllllllllll}0 & 0 & 0 & 0 & 0 & 0 & 0 & 0 & 0 & 0 & 0 & -1 & 0 & 0 & 0 & 0 & 1 & 0 & 0 & 150\end{array}\right]$ \\
\hline M $[0$ & 0 & 0 & 0 & 45 & 0 & 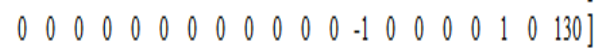 \\
\hline M $[0$ & 0 & 0 & 0 & 0 & 75 & $\left.\begin{array}{llllllllllllllllllll}0 & 0 & 0 & 0 & 0 & 0 & 0 & 0 & 0 & 0 & 0 & 0 & 0 & -1 & 0 & 0 & 0 & 0 & 1 & 200\end{array}\right]$ \\
\hline
\end{tabular}

Tabel 2. Persamaan-Persamaan Koefisien Linear Programming

\begin{tabular}{|c|c|c|c|c|c|c|c|c|c|c|c|c|c|c|c|c|c|c|c|c|c|c|c|c|c|c|c|}
\hline Var.Dsr & $\mathrm{Z}$ & $x_{1}$ & $x_{2}$ & $x_{3}$ & $x_{4}$ & $x_{5}$ & $s_{1}$ & $s_{2}$ & $s_{3}$ & $s_{4}$ & $s_{5}$ & $s_{6}$ & $s_{7}$ & $s_{8}$ & $s_{9}$ & $s_{10}$ & $s_{11}$ & $s_{12}$ & $s_{13}$ & $s_{1}$ & $r_{1}$ & $r_{2}$ & $r_{3}$ & $r_{4}$ & $r_{5}$ & NK & Indeks \\
\hline Z & 1 & $-50 \mathrm{M}-32500$ & $-40 \mathrm{M}-60000$ & $-60 \mathrm{M}-35000$ & $-45 \mathrm{M}-45000$ & $-75 \mathrm{M}-87500$ & 0 & 0 & 0 & 0 & 0 & 0 & 0 & 0 & 0 & $\mathrm{M}$ & M & $\mathrm{M}$ & $\mathrm{M}$ & M & 0 & 0 & 0 & 0 & 0 & $-731 \mathrm{M}$ & \\
\hline$s_{1}$ & 0 & 13 & 0 & 0 & 0 & 0 & 1 & 0 & 0 & 0 & 0 & 0 & 0 & 0 & 0 & 0 & 0 & 0 & 0 & 0 & 0 & 0 & 0 & 0 & 0 & 80000 & $\sim$ \\
\hline$s_{2}$ & 0 & 0 & 12 & 0 & 0 & 0 & 0 & 1 & 0 & 0 & 0 & 0 & 0 & 0 & 0 & 0 & 0 & 0 & 0 & 0 & 0 & 0 & 0 & 0 & 0 & 50000 & $\sim$ \\
\hline$s_{3}$ & 0 & 0 & 0 & 15 & 0 & 0 & 0 & 0 & 1 & 0 & 0 & 0 & 0 & 0 & 0 & 0 & 0 & 0 & 0 & 0 & 0 & 0 & 0 & 0 & 0 & 35000 & $\sim$ \\
\hline$s_{4}$ & 0 & 0 & 0 & 0 & 13 & 0 & 0 & 0 & 0 & 1 & 0 & 0 & 0 & 0 & 0 & 0 & 0 & 0 & 0 & 0 & 0 & 0 & 0 & 0 & 0 & 75000 & $\sim$ \\
\hline$s_{5}$ & 0 & 0 & 0 & 0 & 0 & 20 & 0 & 0 & 0 & 0 & 1 & 0 & 0 & 0 & 0 & 0 & 0 & 0 & 0 & 0 & 0 & 0 & 0 & 0 & 0 & 25000 & 1250 \\
\hline$s_{6}$ & 0 & 23 & 21 & 22 & 25 & 25 & 0 & 0 & 0 & 0 & 0 & 1 & 0 & 0 & 0 & 0 & 0 & 0 & 0 & 0 & 0 & 0 & 0 & 0 & 0 & 600 & 24 \\
\hline$s_{7}$ & 0 & 10 & 5 & 7 & 8 & 9 & 0 & 0 & 0 & 0 & 0 & 0 & 1 & 0 & 0 & 0 & 0 & 0 & 0 & 0 & 0 & 0 & 0 & 0 & 0 & 300 & 33,3333 \\
\hline$s_{8}$ & 0 & 1 & 1 & 1 & 1 & 1 & 0 & 0 & 0 & 0 & 0 & 0 & 0 & 1 & 0 & 0 & 0 & 0 & 0 & 0 & 0 & 0 & 0 & 0 & 0 & 20 & 20 \\
\hline$s_{9}$ & 0 & 3 & 3 & 3 & 3 & 3 & 0 & 0 & 0 & 0 & 0 & 0 & 0 & 0 & 1 & 0 & 0 & 0 & 0 & 0 & 0 & 0 & 0 & 0 & 0 & 90 & 30 \\
\hline$r_{1}$ & 0 & 50 & 0 & 0 & 0 & 0 & 0 & 0 & 0 & 0 & 0 & 0 & 0 & 0 & 0 & -1 & 0 & 0 & 0 & 0 & 1 & 0 & 0 & 0 & 0 & 130 & $\sim$ \\
\hline$r_{2}$ & 0 & 0 & 40 & 0 & 0 & 0 & 0 & 0 & 0 & 0 & 0 & 0 & 0 & 0 & 0 & 0 & -1 & 0 & 0 & 0 & 0 & 1 & 0 & 0 & 0 & 120 & $\sim$ \\
\hline$r_{3}$ & 0 & 0 & 0 & 60 & 0 & 0 & 0 & 0 & 0 & 0 & 0 & 0 & 0 & 0 & 0 & 0 & 0 & -1 & 0 & 0 & 0 & 0 & 1 & 0 & 0 & 150 & $\sim$ \\
\hline$r_{4}$ & 0 & 0 & 0 & 0 & 45 & 0 & 0 & 0 & 0 & 0 & 0 & 0 & 0 & 0 & 0 & 0 & 0 & 0 & -1 & 0 & 0 & 0 & 0 & 1 & 0 & 130 & $\sim$ \\
\hline$r_{5}$ & 0 & 0 & 0 & 0 & 0 & 75 & 0 & 0 & 0 & 0 & 0 & 0 & 0 & 0 & 0 & 0 & 0 & 0 & 0 & -1 & 0 & 0 & 0 & 0 & 1 & 200 & 2,66667 \\
\hline
\end{tabular}

Sumber: Pengolahan Data

Berdasarkan Tabel 2, kolom kunci yang dipilih yaitu pada kolom $x_{5}$ karena nilai $\mathrm{Z}$ terkecil terdapat pada kolom $x_{5}$ yaitu $75 \mathrm{M}-87500$, sedangkan baris kunci terdapat pada baris $r_{5}$ karena memiliki nilai indeks terkecil yaitu 2,67.
4. Mengubah nilai-nilai baris kunci dan mengubah nilai-nilai selain baris kunci Baris kunci yang telah di peroleh pada pengolahan data Tabel 2 diubah dan dibagi dengan angka kunci yang ditetapkan berdasarkan pertemuan antara kolom dan baris kunci. Sehingga diperoleh hasil sebagai berikut: 
Tabel 3. Iterasi 1

\begin{tabular}{|c|c|c|c|c|c|c|c|c|c|c|c|c|c|c|c|c|c|c|c|c|c|c|c|c|c|}
\hline Var.Dsr & Z & $x_{1}$ & $x_{2}$ & $x_{3}$ & $x_{4}$ & $x_{5}$ & & $s_{2}$ & $s_{3}$ & $s_{4}$ & $s_{5}$ & $s_{6}$ & $s_{7}$ & $s_{8}$ & $s_{9} s$ & $10 \mathrm{~s}$ & $s_{11} s$ & ${ }_{12} \mid s_{1}$ & $s_{14}$ & $r_{1}$ & $r_{2}$ & $r_{3}$ & $r_{4}$ & $r_{5}$ & NK \\
\hline Z & 1 & $-50 \mathrm{M}-32500$ & $-40 \mathrm{M}-60000$ & $-60 \mathrm{M}-35000$ & $-45 \mathrm{M}-45000$ & 0 & 0 & 0 & 0 & 0 & 0 & 0 & 0 & 0 & 0 & $\mathrm{M}$ & $\begin{array}{lll}M & .\end{array}$ & $\begin{array}{ll}\mathrm{M} & \mathrm{N}\end{array}$ & $\begin{array}{ll}1 & -3500 / 3 \\
\end{array}$ & 0 & 0 & 0 & 0 & $\mathrm{M}+3500 / 3$ & $.530 \mathrm{M}$ \\
\hline$s_{1}$ & 0 & 13 & 0 & 0 & 0 & 0 & 1 & 0 & 0 & 0 & 0 & 0 & 0 & 0 & 0 & 0 & 0 & 0 & 0 & 0 & 0 & 0 & 0 & 0 & 80000 \\
\hline$S_{2}$ & 0 & 0 & 12 & 0 & 0 & 0 & 0 & 1 & 0 & 0 & 0 & 0 & 0 & 0 & 0 & 0 & 0 & 0 & 0 & 0 & 0 & 0 & 0 & 0 & 50000 \\
\hline$S_{3}$ & 0 & 0 & 0 & 15 & 0 & 0 & 0 & 0 & 1 & 0 & 0 & 0 & 0 & 0 & 0 & 0 & 0 & 0 & 0 & 0 & 0 & 0 & 0 & 0 & 35000 \\
\hline$S_{4}$ & 0 & 0 & 0 & 0 & 13 & 0 & 0 & 0 & 0 & 1 & 0 & 0 & 0 & 0 & 0 & 0 & 0 & 0 & 0 & 0 & 0 & 0 & 0 & 0 & 75000 \\
\hline$S_{5}$ & 0 & 0 & 0 & 0 & 0 & 0 & 0 & 0 & 0 & 0 & 1 & 0 & 0 & 0 & 0 & 0 & 0 & 0 & $4 / 15$ & 0 & 0 & 0 & 0 & $-4 / 15$ & $74840 / 3$ \\
\hline$s_{6}$ & 0 & 23 & 21 & 22 & 25 & 0 & 0 & 0 & 0 & 0 & 0 & 1 & 0 & 0 & 0 & 0 & 0 & 0 & $1 / 3$ & 0 & 0 & 0 & 0 & $-1 / 3$ & $1600 / 3$ \\
\hline$s_{7}$ & 0 & 10 & 5 & 7 & 8 & 0 & 0 & 0 & 0 & 0 & 0 & 0 & 1 & 0 & 0 & 0 & 0 & 0 & $3 / 25$ & 0 & 0 & 0 & 0 & $-3 / 25$ & 276 \\
\hline$S_{8}$ & 0 & 1 & 1 & 1 & 1 & 0 & 0 & 0 & 0 & 0 & 0 & 0 & 0 & 1 & 0 & 0 & 0 & 0 & $1 / 75$ & 0 & 0 & 0 & 0 & $-1 / 75$ & $52 / 3$ \\
\hline$S_{9}$ & 0 & 3 & 3 & 3 & 3 & 0 & 0 & 0 & 0 & 0 & 0 & 0 & 0 & 0 & 1 & 0 & 0 & 0 & $1 / 25$ & 0 & 0 & 0 & 0 & $-1 / 25$ & 82 \\
\hline$r_{1}$ & 0 & 50 & 0 & 0 & 0 & 0 & 0 & 0 & 0 & 0 & 0 & 0 & 0 & 0 & 0 & -1 & 0 & 0 & 0 & 1 & 0 & 0 & 0 & 0 & 130 \\
\hline$r_{2}$ & 0 & 0 & 40 & 0 & 0 & 0 & 0 & 0 & 0 & 0 & 0 & 0 & 0 & 0 & 0 & 0 & -1 & 0 & 0 & 0 & 1 & 0 & 0 & 0 & 120 \\
\hline$r_{3}$ & 0 & 0 & 0 & 60 & 0 & 0 & 0 & 0 & 0 & 0 & 0 & 0 & 0 & 0 & 0 & 0 & 0 & 0 & 0 & 0 & 0 & 1 & 0 & 0 & 150 \\
\hline$r_{4}$ & 0 & 0 & 0 & 0 & 45 & 0 & 0 & 0 & 0 & 0 & 0 & 0 & 0 & 0 & 0 & 0 & 0 & -1 & 0 & 0 & 0 & 0 & 1 & 0 & 130 \\
\hline$x_{5}$ & 0 & 0 & 0 & 0 & 0 & 1 & 0 & 0 & 0 & 0 & 0 & 0 & 0 & 0 & 0 & 0 & 0 & 0 & $-1 / 75$ & 0 & \begin{tabular}{|l|l|}
0 \\
\end{tabular} & 0 & 0 & $1 / 75$ & $8 / 3$ \\
\hline
\end{tabular}

Berdasarkan Tabel 3, di dalam fungsi $\mathrm{Z}$ masih terdapat nilai negatif. Karena fungsi tujuan penelitian ini memaksimalkan maka
$\mathrm{Z}$ harus bernilai positif, sehingga perhitungan yang sama dilakukan hingga fungsi $\mathrm{Z}$ bernilai positif.

Tabel 4. Iterasi 7

\begin{tabular}{|c|c|c|c|c|c|c|c|c|c|c|c|c|c|c|c|c|c|c|c|c|c|c|c|c|c|c|}
\hline Var.Dsr & $\mathrm{Z}$ & $x_{1}$ & $x_{2}$ & $x_{3}$ & & $x_{5}$ & $s_{1}$ & $s_{2}$ & $s_{3}$ & $s_{4}$ & $s_{5}$ & $s_{6}$ & $s_{7}$ & $s_{8}$ & $s_{9}$ & $s_{10}$ & $s_{11}$ & $s_{12}$ & $s_{13}$ & $s_{14}$ & $r_{1}$ & $r_{2}$ & $r_{3}$ & $r_{4}$ & $r_{5}$ & NK \\
\hline Z & 1 & 0 & 0 & 0 & 0 & 0 & 0 & 0 & 0 & 0 & 0 & 0 & 0 & 87500 & 0 & 1100 & $1375 / 2$ & 875 & $38883 / 43$ & 0 & $\mathrm{M}$ & M & $\mathrm{M}$ & $\mathrm{M}$ & M & 1270472 \\
\hline$s_{1}$ & 0 & 0 & 0 & 0 & 0 & 0 & 1 & 0 & 0 & 0 & 0 & 0 & 0 & 0 & 0 & $13 / 50$ & 0 & 0 & 0 & 0 & $-13 / 50$ & 0 & 0 & 0 & 0 & $399831 / 5$ \\
\hline$s_{3}$ & 0 & 0 & 0 & 0 & 0 & 0 & 0 & 0 & 1 & 0 & 0 & 0 & 0 & 0 & 0 & 0 & 0 & $1 / 4$ & 0 & 0 & 0 & 0 & $-1 / 4$ & 0 & 0 & $69925 / 2$ \\
\hline$s_{4}$ & 0 & 0 & 0 & 0 & 0 & 0 & 0 & 0 & 0 & 1 & 0 & 0 & 0 & 0 & 0 & 0 & 0 & 0 & $13 / 47$ & 0 & 0 & 0 & 0 & $-13 / 47$ & 0 & 74964 \\
\hline$s_{7}$ & 0 & 0 & 0 & 0 & 0 & 0 & 0 & 0 & 0 & 0 & 0 & 0 & 1 & -9 & 0 & $1 / 50$ & $-1 / 10$ & $-1 / 30$ & $-1 / 47$ & 0 & $-1 / 50$ & $1 / 10$ & $1 / 30$ & $1 / 47$ & 0 & $32234 / 235$ \\
\hline$s_{14}$ & 0 & 0 & 0 & 0 & 0 & 0 & 0 & 0 & 0 & 0 & 0 & 0 & 0 & 75 & 0 & $3 / 2$ & $15 / 8$ & $5 / 4$ & $75 / 47$ & 1 & $-3 / 2$ & $-15 / 18$ & $5 / 4$ & $-75 / 47$ & -1 & $45595 / 94$ \\
\hline$s_{9}$ & 0 & 0 & 0 & 0 & 0 & 0 & 0 & 0 & 0 & 0 & 0 & 0 & 0 & -3 & 1 & $1 / 2147$ & $1 / 2147$ & $1 / 2147$ & $1 / 2147$ & 0 & $-1 / 2147$ & $-1 / 2147$ & $-1 / 2147$ & $-1 / 2147$ & 0 & 30 \\
\hline$x_{1}$ & 0 & 1 & 0 & 0 & 0 & 0 & 0 & 0 & 0 & 0 & 0 & 0 & 0 & 0 & 0 & $-1 / 50$ & 0 & 0 & 0 & 0 & $1 / 50$ & 0 & 0 & 0 & 0 & $13 / 5$ \\
\hline$x_{5}$ & 0 & 0 & 0 & 0 & 0 & 1 & 0 & 0 & 0 & 0 & 0 & 0 & 0 & 1 & 0 & $1 / 50$ & $1 / 40$ & $1 / 60$ & $1 / 47$ & 0 & $-1 / 50$ & $-1 / 40$ & $-1 / 60$ & $-1 / 47$ & 0 & $4293 / 470$ \\
\hline
\end{tabular}

Sumber: Pengolahan Data

Berdasarkan Tabel 4 iterasi yang dilakukan hingga 7 kali iterasi untuk memperoleh hasil $\mathrm{Z}$ yang positif sehingga kesimpulan yang dapat di tarik dari pengolahan data adalah sebagai berikut:

$$
\begin{array}{lll}
\mathrm{Z} & =1.270 .472 & \\
x_{1}=13 / 5 & \rightarrow 2,6 \\
x_{2}=3 & & \\
x_{3} & =5 / 2 & \rightarrow 2,5 \\
x_{4} & =130 / 47 & \rightarrow 2,8 \\
x_{5} & =4293 / 470 & \rightarrow 9,1
\end{array}
$$

Perusahaan akan memperoleh keuntungan maksimum dengan produksi yang dilakukan selama 1 kali produksi untuk ekstrak buah jambu merah adalah sebesar $2,6 \mathrm{~kg}$, ekstrak buah sirsak sebesar $3 \mathrm{~kg}$, ekstrak buah nanas sebesar 2,5 kg, ekstrak buah mangga sebesar $2,8 \mathrm{~kg}$ dan ekstrak buah lemon sebesar 9,1 kg.Pengolahan data dilakukan dengan menggunakan $Q M$ for Windows. Berikut adalah input fungsi kendala ke dalam QM For Windows: 
Tabel 5. Input fungsi kendala ke dalam QM For Windows

\begin{tabular}{|c|c|c|c|c|c|c|c|c|}
\hline & $\mathrm{X} 1$ & $\mathrm{X} 2$ & $\mathrm{X} 3$ & $\mathrm{X} 4$ & $\mathrm{X} 5$ & & RHS & Equation form \\
\hline Maximize & 32500 & 60000 & 35000 & 45000 & 87500 & & & $\operatorname{Max} 32500 \times 1+60000 \times 2+35 \ldots$ \\
\hline Buah Jambu Biji Merah & 13 & 0 & 0 & 0 & 0 & $<=$ & 80000 & $13 \times 1<=80000$ \\
\hline Buah Sirsak & 0 & 12 & 0 & 0 & 0 & $<=$ & 50000 & $12 \times 2<=50000$ \\
\hline Buah Nanas & 0 & 0 & 15 & 0 & 0 & $<=$ & 35000 & $15 \times 3<=35000$ \\
\hline Buah Mangga & 0 & 0 & 0 & 13 & 0 & $<=$ & 75000 & $13 \times 4<=75000$ \\
\hline Buah Lemon & 0 & 0 & 0 & 0 & 20 & $<=$ & 25000 & $20 \times 5<=25000$ \\
\hline Fruktosa & 23 & 21 & 22 & 25 & 25 & $<=$ & 600 & $23 \times 1+21 \times 2+22 \times 3+25 \times 4+\ldots$ \\
\hline Asam Sitrat & 10 & 5 & 7 & 8 & 9 & $<=$ & 300 & $10 \times 1+5 \times 2+7 \times 3+8 \times 4+9 X$ \\
\hline Tenaga Kerja & 1 & 1 & 1 & 1 & 1 & $<=$ & 20 & $X 1+X 2+X 3+X 4+X 5<=20$ \\
\hline Waktu & 3 & 3 & 3 & 3 & 3 & $<=$ & 90 & $3 \times 1+3 \times 2+3 \times 3+3 \times 4+3 \times 5 \ldots$ \\
\hline Permintaan Ekstrak Jambu & 50 & 0 & 0 & 0 & 0 & $>=$ & 130 & $50 \times 1>=130$ \\
\hline Permintaan Ekstrak Sirsak & 0 & 40 & 0 & 0 & 0 & $>=$ & 120 & $40 \times 2>=120$ \\
\hline Permintaan Ekstrak Nanas & 0 & 0 & 60 & 0 & 0 & $>=$ & 150 & $60 \times 3>=150$ \\
\hline Permintaan Ekstrak Mangga & 0 & 0 & 0 & 45 & 0 & $>=$ & 130 & $45 \times 4>=130$ \\
\hline Permintaan Ekstrak Lemon & 0 & 0 & 0 & 0 & 75 & $>=$ & 200 & $75 \times 5>=200$ \\
\hline
\end{tabular}

\section{Linier Programming Result}

Tabel 6. Linier Programming Result

\begin{tabular}{|c|c|c|c|c|c|c|c|c|}
\hline & $\begin{array}{l}\text { Ekstrak } \\
\text { Jambu }\end{array}$ & $\begin{array}{l}\text { Ekstrak } \\
\text { Sirsak }\end{array}$ & $\begin{array}{l}\text { Ekstrak } \\
\text { Nanas }\end{array}$ & $\begin{array}{l}\text { Ekstrak } \\
\text { Mangga }\end{array}$ & $\begin{array}{l}\text { Ekstrak } \\
\text { Lemon }\end{array}$ & & RHS & Dual \\
\hline Maximize & 32500 & 60000 & 35000 & 45000 & 87500 & & & \\
\hline Buah Jambu Biji Merah & 13 & 0 & 0 & 0 & 0 & $<=$ & 80000 & 0 \\
\hline Buah Sirsak & 0 & 12 & 0 & 0 & 0 & $<=$ & 50000 & 0 \\
\hline Buah Nanas & 0 & 0 & 15 & 0 & 0 & $<=$ & 35000 & 0 \\
\hline Buah Mangga & 0 & 0 & 0 & 13 & 0 & $<=$ & 75000 & 0 \\
\hline Buah Lemon & 0 & 0 & 0 & 0 & 20 & $<=$ & 25000 & 0 \\
\hline Fruktosa & 23 & 21 & 22 & 25 & 25 & $<=$ & 600 & 0 \\
\hline Asam Sitrat & 10 & 5 & 7 & 8 & 9 & $<=$ & 300 & 0 \\
\hline Tenaga Kerja & 1 & 1 & 1 & 1 & 1 & $<=$ & 20 & 87500 \\
\hline Waktu & 3 & 3 & 3 & 3 & 3 & $<=$ & 90 & 0 \\
\hline Permintaan Ekstrak Jam.. & 50 & 0 & 0 & 0 & 0 & $>=$ & 130 & -1100 \\
\hline Permintaan Ekstrak Sirsak & 0 & 40 & 0 & 0 & 0 & $>=$ & 120 & $-687,5$ \\
\hline Permintaan Ekstrak Nanas & 0 & 0 & 60 & 0 & 0 & $>=$ & 150 & -875 \\
\hline Permintaan Ekstrak Man... & 0 & 0 & 0 & 45 & 0 & $>=$ & 130 & $-944,44$ \\
\hline Permintaan Ekstrak Lemon & 0 & 0 & 0 & 0 & 75 & $>=$ & 200 & 0 \\
\hline Solution & 2,6 & 3 & 2,5 & 2,89 & 9,01 & & 1270472,0 & \\
\hline
\end{tabular}

Tabel 6. merupakan output dari pengolahan data menggunakan POM QM. Didapatkan solusi bahwa untuk mendapatkan keuntungan maksimal, produksi yang dilakukan per sekali produksi adalah sebanyak 2,6 kg ekstrak buah jambu biji merah, $3 \mathrm{~kg}$ ekstrak buah sirsak, 2,5 kg ekstrak buah nanas, $2,89 \mathrm{~kg}$ ekstrak buah mangga dan 9,01 kg ekstrak buah lemon dengan keuntungan sebesar $\mathrm{Rp}$ 1.270.472,- 


\section{Ranging}

Tabel 7. Ranging Result

\begin{tabular}{|c|c|c|c|c|c|}
\hline Variable & Value & Reduced & Original Val & Lower Bou. & Upper Bou.. \\
\hline Ekstrak Jambu & 2,6 & 0 & 32500 & -Infinity & 87500 \\
\hline Ekstrak Sirsak & 3 & 0 & 60000 & -Infinity & 87500 \\
\hline Ekstrak Nanas & 2,5 & 0 & 35000 & -Infinity & 87500 \\
\hline Ekstrak Mangga & 2,89 & 0 & 45000 & -Infinity & 87500 \\
\hline \multirow[t]{2}{*}{ Ekstrak Lemon } & 9,01 & 0 & 87500 & 60000 & Infinity \\
\hline & Dual Value & Slack/Surp... & Original Val & Lower Bou... & Upper Bou... \\
\hline Buah Jambu Biji Merah & 0 & 79966,2 & 80000 & 33,8 & Infinity \\
\hline Buah Sirsak & 0 & 49964 & 50000 & 36 & Infinity \\
\hline Buah Nanas & 0 & 34962,5 & 35000 & 37,5 & Infinity \\
\hline Buah Mangga & 0 & 74962,45 & 75000 & 37,55 & Infinity \\
\hline Buah Lemon & 0 & 24819,78 & 25000 & 180,22 & Infinity \\
\hline Fruktosa & 0 & 124,7 & 600 & 475,3 & Infinity \\
\hline Asam Sitrat & 0 & 137,29 & 300 & 162,71 & Infinity \\
\hline Tenaga Kerja & 87500 & 0 & 20 & 13,66 & 24,99 \\
\hline Waktu & 0 & 30 & 90 & 60 & Infinity \\
\hline Permintaan Ekstrak Jam... & -1100 & 0 & 130 & 0 & 447,22 \\
\hline Permintaan Ekstrak Sirsak & $-687,5$ & 0 & 120 & 0 & 373,78 \\
\hline Permintaan Ekstrak Nanas & -875 & 0 & 150 & o & 530,67 \\
\hline Permintaan Ekstrak Man... & $-944,44$ & 0 & 130 & 0 & 415,5 \\
\hline Permintaan Ekstrak Lemon & o & 475,83 & 200 & -Infinity & 675,83 \\
\hline
\end{tabular}

Tabel 7. merupakan ranging result, tampilan Ranging khususnya pada kolom lower bond dan upper bound menunjukan batas minimum dan maksimum pada koefisien variabel dan pada nilai kendala, dimana pada rentang nilai antara lower bond dan upper bond, penambahan atau pengurangan koefisien variabel atau nilai kendala. Reduced cost menunjukkan seberapa besar nilai koefisien fungsi tujuan dan masing-masing variabel harus ditambah agar variabel keputusan tersebut bernilai positif pada solusi optimal. Kerena nilai tabel diatas 0 , maka nilai koefisien fungsi tujuannya sudah positif. Dual Value menunjukkan nilai dari setiap variabel pada solusi optimal, untuk menghasilkan optimal sebesar 87500 untuk tenaga kerja. Slack/surplus adalah sisa yang tidak digunakan dalam prosesp roduksi. Waktu sisa yang tidak digunakan sebesar 30 jam, sedangkan penggunaan yang belum optimal karena kapasitas original valuenya sebesar 90 jam sehingga waktu proses produksi hanya 60 jam.

\section{SIMPULAN}

PT KBDTI mempunyai 14 kendala pada proses produksi. Perencanaan produksi pada PT KBDTI dapat dipandang sebagai masalah linear programming. Hal ini sangat membantu manager produksi dalam menentukkan jumlah bahan baku yang digunakan untuk mendapatkan keuntungan yang optimal. Berdasarkan hasil perhitungan yang telah dilakukan baik secara manual maupun dengan bantuan QM for Windows diambil kesimpulan bahwa PT KBDTI dapat memperoleh keuntungan optimal sebesar Rp 1.270.472 dengan memproduksi ekstrak buah jambu biji merah sebesar 2,6 kg, ekstrak buah sirsak sebesar $3 \mathrm{~kg}$, ekstrak buah nanas sebesar 2,5 kg, ekstrak buah mangga sebesar 2,89 kg dan ekstrak buah lemon sebesar $9 \mathrm{~kg}$. Keuntungan yang diperoleh PT KBDTI melalui perhitungan metode simpleks ini lebih meningkat sebsar $57 \%$ dibandingkan dengan keuntungan sebelumnya. 
DAFTAR PUSTAKA

[1] Falani, I. (2018). Penentuan Nilai Parameter Metode Exponential Smoothing Dengan Algoritma Genetik Dalam Meningkatkan Akurasi Forecasting. CESS Unimed, 3(1), 14-16.

[2] Pushpavalli, D. K., Subasree, D. P., \& Umadev, D. S. (2018). Decision Making In Agriculture: A Linear Programming Approach. International Journal Of Mathematical Archive, 9, 120-121.

[3] Krynke, M., \& Mielczarek, K. (2018). Applications Of Linear Programming To Optimize The CostBenefit Criterion In Production Processes. 4004, 2-3.

[4] Oladejo, N. K., Abolarinwa, A., Salawu, S. ., \& Lukman, A. . (2019). Optimization Principle And Its' Application In Optimizing Landmark University Bakery Production Using Linear Programming. International Journal Of Civil Engineering And Technology (IJCIET), 10(2), 183190.

[5] Firmansyah, Dedy Juliandri
Panjaitan, Madyunus Salayan, A. D. S. (2018). Pengoptimalan Keuntungan Badan Usaha Karya Tani Di Deli Serdang Dengan Metode Simpleks. Jistech, 3(1), 20.

[6] Hamdy A. Taha. (1996). Riset Operasi - Suatu Pengantar. Edisi Kelima. Binarupa Aksara. Jakarta

[7] Wijaya Andi, 2012. Pengantar Riset Operasi. Edisi Ketiga. Mitra Wacana Media. Jakarta

[8] Wayne L. Winston. (1971). Operations Research. In Mathematics In Science And Engineering (Vol. 73). Https://Doi.Org/10.1016/S00765392(08)62705-8

[9] Velinov, A., \& Gicev, V. (2018). PRACTICAL APPLICATION OF SIMPLEX METHOD FOR SOLVING LINEAR PROGRAMMING PROBLEMS. BALKAN JOURNAL OF APPLIED MATHEMATICS AND, 1(August), 9-10.

[10] Prasetyaningrum Susanti \&Ni'matuzahroh. (2014). Observasi Dalam Psikologi. Malang: UMM Press 